\title{
Esfilagarsats i entortolligats: Una ullada als cossos des del posthumanisme
}

\section{Unraveled and entangled: a glimpse at the bodies from posthumanism}

Josep Martí 


\section{Abstract}

In this article I present some ideas related to the posthumanist thinking concerning bodies. Trying to understand the reality by overcoming conceptual schemes of Cartesian dualism, anthropocentrism and biocentrism, the post-humanist notion of the body is based on different presuppositions from those of humanism. It does not conceive the body as a mere support of the mind but instead departs from the embodiment concept, but understanding this idea in a wider form as it was originally formulated by Thomas Csordas. The body is conceptualized as an assemblage of different elements which only becomes understandable through intra-actions (Karen Barad) with everything that surrounds it, unlike the classical vision that considers the body as a unified organic whole separated from its surroundings. The body does not end at the skin (Donna Haraway). In this way, the boundaries of the body, so clearly established by epistemological structures, which are profoundly anthropocentric and based on individual/ society and $\mathrm{mind} /$ body dualities are blurred in the conceptual framework of posthumanism. Within the characteristic non dualist ontology of posthumanism what counts are relations not entities. The body is understood rather than in terms of what it is, according to its capacity of action and interaction (Gilles Deleuze).

\section{Keywords:}

body, posthumanism, agency, relationality, affect 


\section{Resum}

En aquest article es presenten algunes idees pròpies del pensament posthumanista en relació als cossos. Tot intentant entendre la realitat mitjançant la superació d'esquemes conceptuals del dualisme cartesià, l'antropocentrisme i el biocentrisme, la noció posthumanista del cos es basteix sobre pressupòsits molt diferents als de l'humanisme. No concep el cos com a mer suport de la ment sinó que parteix de la idea d'embodiment, però entenent aquest concepte de forma més àmplia de com fou originàriament formulada per Thomas Csordas. El cos se'l conceptualitza com un assemblatge de diferents elements que només resulta comprensible a partir de les intra-accions (Karen Barad) amb tot allò que l'envolta, a diferència de la visió clàssica de considerar-lo com un tot orgànic unificat i separat del seu entorn. Els nostres cossos van molt més enllà de la pell que els recobreix (Donna Haraway). D'aquesta manera, els límits del cos, tan clarament establerts per estructures epistemològiques pregonament antropocèntriques i molt marcades per les dualitats individu/societat i ment/cos, es desdibuixen en el marc conceptual del posthumanisme. Dins de l'ontologia de caire no dualista característica del posthumanisme és a les relacions abans que a les entitats a allò que se li atorga una major importància. El cos és entès - més que en termes del que és- segons les seves capacitats d'acció i interacció (Gilles Deleuze).

Paraules clau:

cos, posthumanisme, agència, relacionalitat, afecte 


\section{Introducció}

L'antropòleg sap que per arribar a conèixer allò que pretén estudiar, el primer que ha de fer és intentar escapar-se d'ell mateix. Al llarg de la història de la disciplina hom ha hagut d'esdevenir conscient de tot allò que l'impedeix intentar entendre l'altre. La superació de l'etnocentrisme fou possiblement el primer gran cavall de batalla en aquest sentit. Posteriorment, el fet de prendre consciència de l'androcentrisme, tant de la societat en general com de la ciència en particular, revelà que calia trencar la pregona crosta androcèntrica per assolir un coneixement més acurat del que és l'ésser humà. Ara, sense que ni l'etnocentrisme ni l'androcentrisme es puguin considerar completament superats, el posthumanisme ens demana anar encara més enllà. Sabem que el que cal canviar és la nostra manera antropocèntrica d'entendre la vida i la realitat en general: "Els humans ja no són els reis dels éssers sinó que es troben entre éssers, entortolligats amb éssers i implicats amb altres éssers" (Bogost, 2012: 16) ${ }^{1}$.

Ja fa força temps que Norbert Elias criticà amb encert el concepte tradicional d'“individu", una imatge ideal en la que se l'entén autocontingut en ell mateix (1978: 119). La superació d'aquesta idea constitueix un punt central dins de l'actual pensament posthumanista; cal descentrar-nos. I una de les vies que ens obliga a qüestionar-nos l'homo clausus del qual parlava el sociòleg alemany és reflexionar sobre la problemàtica de les agències, és a dir, dels efectes que una entitat qualsevol té sobre una altra.

Un senzill exemple servirà per introduir-nos en la problemàtica. Ara mateix em trobo assegut a l'escriptori fent anotacions amb un llapis. Podem afirmar que:

1. Cal reconèixer que el meu llapis em toca, no només que jo toco el llapis.

2. No és que siguem jo i un llapis, sinó que en el moment en que empro el llapis jo esdevinc un home-llapis.

3. Allò important no és què és o què significa aquest home-llapis sinó què fa o què pot fer.

La primera idea fa al·lusió directa a les agències. En contra del que es podia pensar abans, el pensament posthumanista reconeix que el fet d'exercir agència no és propietat exclusiva dels éssers humans. Qualsevol cosa, sigui ja entesa com a organisme viu o com a objecte inert exerceix
${ }^{1}$ Totes les traduccions que apareixen al llarg de l'article són de l'autor. 
agències. En la segona, partim de la base que els cossos són processos, que esdevenen cossos mitjançant relacions; entenem que l'home-llapis constitueix un assemblatge en el sentit de Gilles Deleuze i Félix Guattari. I en la tercera idea, defugim de les aproximacions teòriques representacionals i entrem en l'àmbit dels afectes.

Si som capaços d'entendre això, estem començant a descentrar-nos. Escapar d'aquest homo clausus vol dir fer-nos nostre el pensament que en un moment determinat no és que siguem jo i un llapis sinó que jo sóc el producte de la relació entre el llapis i el meu jo. Aquest exemple ens duu a allò que constantment planejarà al llarg d'aquest article: quines són les fronteres del cos? Fins a quin punt tot el que ens envolta, per exemple els objectes, pot arribar a ser nosaltres; o nosaltres ells?

\section{Els objectes exerceixen agència}

Talment com ja vaig escriure en una altra ocasió (Martí, 2016), els objectes $^{2}$ ens conviden a fer coses amb ells. Ens generen admiració (obra d'art, pedra preciosa), repulsió (una immundícia al mar quan ens banyem), curiositat (quelcom desconegut), amor (havia pertangut a una persona admirada), devoció (imatge d'un sant), impotència (l'aparell electrònic que no aconseguim posar en funcionament), ràbia (el cotxe que no arrenca per manca de bateria), seguretat (el despertador que em garantirà no perdre l'avió), etc. Fins i tot parlem de 1'“objecte passió", terme que Jean Baudrillard emprava per descriure allò que mou el col·leccionista (1969: 99). Tot això és el resultat de la capacitat d'agència que tenen els objectes, de la seva capacitat d'afectar.

Els objectes també interaccionen entre ells; entre ells i els éssers animats. No és el mateix una atzavara vista a la muntanya que en un test, i segons com sigui aquest test, amb més o menys estil, la veurem diferent. No és el mateix una persona vestida amb roba de marca que sense. Un marc, mai més ben dit, emmarca, terme que per ell mateix ja apunta a una relació de forces. Els objectes modifiquen allò que els acompanya: els realcen, els complementen, els acaronen, els emmascaren o fins i tot els neguen. Això ho saben molt bé els tècnics de màrqueting. Un embolcall pot ser important $\mathrm{i}$ àdhuc decisiu per tal que hom acabi caient en la temptació de fer-se seu allò que embolcalla.

Els objectes, doncs, també exerceixen agència. La tassa decorada amb motius londinencs amb la qual em prenc el cafè cada matí em fa recor-

\begin{abstract}
${ }^{2}$ Al llarg d'aquest article parlarem de "coses" i d'"objectes", dos termes generalment intercanviables però que també, en ocasions, convé distingir. Les "coses" esdevenen "objectes" en ésser definides, anomenades, incorporades a l'àmbit experiencial de l'individu (Leeuw, 2008: 222) o, en paraules de Fernando Domínguez, mentre que les "coses" es poden entendre com processos materials que es donen en el temps, els "objectes" són les posicions que se les fa ocupar per tal de participar en diferents règims de valor i significat (2016: 61).
\end{abstract}


dar el meu viatge a aquesta ciutat; la cadira sobre la qual m'assec fa que no caigui de cul a terra per raons de la gravetat; el soroll d'arrencada del motor de la nevera que tinc a prop fa que em desconcentri; la lentitud de l'ordinador em fa posar de mal humor; la reproducció del Gauguin que tinc penjada al meu davant m'inspira, etc. No acabaríem mai. Aquests objectes i qualsevol altre dels que giren al meu voltant exerceixen la seva agència sobre mi. Són el que Bruno Latour anomenava "actants", qualsevol cosa que modifiqui amb la seva incidència un estat de coses; tot allò que actua o mou a l'acció, sigui humà o no humà (Akrich i Latour, 1992: 259). Per això diem que una obra d'art —o fins i tot un objecte qualsevol que apreciem- ens captiva. El verb "captivar" és el millor indicatiu que estem parlant d'“agències”, l'efecte o poder que quelcom exerceix sobre nosaltres. Ens atrauen, com la força de la gravetat atrau els cossos. Malament li aniria al negoci publicitari si no fos per la capacitat d'agència que tenen els anuncis que sembra arreu de la ciutat. Els missatges dels cartells, dels grafits, de les pintades subversives, dels il-limitats rètols i avisos que inunden els carrers ens atrauen la mirada, ens desvien dels nostres pensaments i ens fan llegir-los sense que ho pretenguem. Això també forma part de la contaminació urbana: és la pol·lució informacional.

Des de la perspectiva humanista s'entenia l'agència com a una característica innata d'un subjecte intencional i lliure, entès de forma essencialista, que li permet actuar en i sobre el món (Mazzei, 2013: 733). Òbviament, al marge de les filosofies de caire animista, difícilment es pot atorgar intencionalitat als objectes; la qüestió és, però, fins a quin punt la idea d'intencionalitat és essencial per parlar d'“agència”. Tot i que encara sense saber escapolir-se de la mirada antropocèntrica, el reconegut sociòleg Anthony Giddens havia d'admetre que les agències resultants de les accions de l'individu no havien de ser sempre intencionals (Giddens, 1984: 8-14). Tot i que aquest sociòleg considerava la intencionalitat com un element clau de l'agència, adoptà també la idea de Sherry Ortner d'una definició soft d'agència en la qual es relativitza el requisit de la intencionalitat (Ahearn, 2010: 34). Alfred Gell, interessat en l'antropologia de l'art, distingeix entre "agents primaris" $i$ "agents secundaris" segons se'ls atorgui o no intencionalitat. Però en aquesta distinció inclou ja una idea interessant: entre els agents secundaris cal entendre també els objectes (Gell, 1998: 20). I els cossos també exerceixen agència en aquest sentit. En situacions determinades, els cossos, com qualsevol altre objecte, ens reclamen la mirada sense que hagi estat la nostra intenció mirar-los, ni veiem en ells la persona. No estem parlant d'individus, 
estem parlant de materialitats. I qui diu un cos, diu un fragment de cos: uns ulls, unes sines, una gesticulació que ens sembla capritxosa, una mà a la qual li manca un dit... Segons escrivia Sharon Krause, el cos humà fa més que no proveir motius i ésser vehicle d'agències, talment com ja s'entén habitualment. De la mateixa manera que un objecte qualsevol, el cos humà té, per ell mateix, "agentic capacities” (2011: 300).

El característic model dicotòmic d'occident sempre ha entès en relació d'oposició les coses i els individus, el món de la matèria inerta i els éssers vius, conceptualitzant els humans com a éssers autònoms. Un dels aspectes, però, que resulta interessant d'aquesta distinció és que el cos ha quedat entre aquests dos pols. En ocasions se l'identifica amb la persona i en altres pren la categoria d'objecte, com en el cas dels cadàvers o dels fragments corporals (Esposito, 2015: 3). Aquesta basculació entre els dos pols és precisament allò que, en ocasions, ens fa sentir un cert desassossec quan el cadàver acaba prenent el rang d'objecte artístic o d'exhibició per raons que van més enllà de la persona o que àdhuc la ignoren ${ }^{3}$. Tot i que no hem d'equiparar completament persona a individu - històricament persona és un estatus legal variable segons relacions de poder- talment com afirma Roberto Esposito, a occident el paradigma de persona va produir no una unió sinó una separació. Però no només va separar alguns dels altres, les persones de les no-persones, sinó àdhuc l'individu de la seva mateixa materialitat o entitat biològica: el cos (Esposito, 2015: 30).

La noció d'“agència" constitueix un nucli conceptual important dins de les teories posthumanistes, entenent-la sempre de forma relacional i contextualment dependent. I la no menys important idea de relacionalitat, és a dir, el reconeixement explícit que tot en el nostre món es troba intrínsecament relacionat, ens duu també a parlar d'“agència distributiva" (Bennett, 2010), en el sentit que ésser un subjecte no és actuar de forma autònoma vers un transfons objectiu sinó compartir agència amb altres subjectes que també han perdut la seva autonomia (Latour, 2014: 5). No s'entén agència com una propietat o capacitat interna d'un ens sinó una qualitat emergent a partir de les interaccions entre cossos, ja siguin humans o no humans (Krause, 2011: 300). Per tant, hom no té agència sinó que aquesta és producte de relacions. Parlar d'agència distributiva significa que no hi ha un únic subjecte com a causa d'un efecte sinó que hi ha tota una munió de vitalitats en joc (Bennett, 2010: 31). Al darrere d'aquests posicionaments planeja també la idea de la "simetria generalitzada”, el fet d'anivellar des del punt de vista ontològic humans i no humans (Callon, 1986: 200), aspecte que ha estat ben assumit
${ }^{3}$ No resulta difícil trobar exemples en aquest sentit. Recordem l'enrenou que es va produir amb l'anomenat cas "negre de Banyoles", el cos dissecat d'un home africà exposat al museu Darder de Banyoles des de principis del segle XX i que després de la denúncia d'Alphons Arcelin l'any 1991 acabà essent repatriat a Botswana (al respecte vegeu: Westerman, 2006). També hi hagué força polseguera amb l'exposició Bodies que fa alguns anys va recórrer mitja Europa passant també per Barcelona i en la qual, amb ànim de lucre, s'exposaven cadàvers plastinats procedents de presidiaris xinesos (vegeu: http://thestirrer.thebirminghampress.com/january09/ bodies-of-evidence-050110. html; http://thestirrer.thebirminghampress.com/january09/ bodies-not-revealed-0101101. html [data de consulta: març de 2017]). Ignoro si tots els duaners tenen clars els criteris que han d'adoptar quan en el tràfic entre museus a través de fronteres internacionals es troben amb una mòmia. Cal donar-li el tractament d'un cadàver? D'un objecte artístic? D'un objecte arqueològic? 
per l'anomenat "posthumanisme metodològic" (Sharon, 2014: 49) ${ }^{4}$. Es tracta de superar el que Wolfgang Welsch anomenà el principi antròpic per referir-se al fet d'aquesta forma de pensar congriada per la modernitat segons la qual l'ésser humà és el punt de partença de tot, i que tot cal referir-ho a l'ésser humà (Welsch, 2014: 18). Un tema central en el posthumanisme és el de focalitzar l'atenció en les interaccions entre agències humanes i no humanes, conscients que el món es fa i es desfa constantment a partir d'encontres que, per cert, no han de ser forçosament aquells que esperem d'antuvi (Puig, 2009: 310). Ens movem per tant dins del marc d'ontologies relacionals definibles per la màxima que being is relating (Ibid., 309).

Agència és la capacitat d'afectar; per tant, parlar d'agència vol dir també parlar d'afectes en el sentit spinozià, que s'entenen precisament com la capacitat d'afectar i ésser afectat que implica una experiència no conscient d'intensitats, una força experiencial o font d'energies que es troba i mescla amb altres cossos, ja siguin orgànics o inorgànics (Colman, 2010: 12). Estem parlant, per tant, de forces dinàmiques que trenquen la dicotomia cos/ment. Un objecte, un cos ens genera sentiments que es tradueixen en emocions, enteses aquestes com la fixació sociolingüística d'una intensitat. Els afectes són prepersonals ${ }^{5}$, els sentiments són personals i les emocions són socials (Shouse, 2005). Pensar en termes d'afectes en relació als objectes, en relació als cossos, ens fa pensar el món més enllà del que creiem que són les coses, o més enllà de les significacions que conscientment els atorguem. Talment com encertadament critica Nigel Thrift, probablement el 95\% del pensament corporeïtzat és no cognitiu però la reflexió acadèmica se centra de forma exclusiva en un 95\% en la dimensió cognitiva del jo conscient (Thrift, 2000: 36). L'afecte també es una forma de pensar, tot i que sovint indirecta i no reflexiva ${ }^{6}$.

Més enllà dels usos, funcions o significacions que podem atorgar o reconèixer en qualsevol tipus de cos, orgànic o inorgànic, cal pensar també en termes de "significància". El significat és allò al qual ens remet quelcom en qualitat de signe. La significància, en canvi, transcendeix el significat i té a veure amb la dimensió afectiva, és a dir, com qualsevol tipus d'objecte semiòtic afecta un individu en un moment determinat. És clar que la tassa londinenca amb la qual jo em prenc el cafè cada matí em remet a Londres, un fet a l'abast de qualsevol persona que reconegui la trivial imatge del Big Ben que hi figura. Però només jo puc sentir l'afecte pregonament corporal que em produeix, pel fet que — com si es tractés d'una regurgitació- em fa sentir a la pell unes sensacions arran de la meva experiència londinenca. I aquest sentiment, personal, quan
${ }^{4}$ Dins del posthumanisme hi ha diversos corrents, en part a causa de la seva diferent procedència acadèmica $(\mathrm{al}$ respecte vegeu Miah, 2009). L'anomenat "posthumanisme metodològic" té un especial interès a conceptualitzar marcs d'anàlisi adequats per entendre les zones d'intersecció entre humans/no humans (Sharon, 2014: 6).

${ }^{5}$ Són prepersonals en el sentit que no estan subjectes a les limitacions de la consciència o de les representacions.

\author{
6 "Affect is a different kind of \\ intelligence about the world, \\ but it is intelligence none-the- \\ less, and previous attempts \\ which have either relegated \\ affect to the irrational or raised \\ it up to the level of the sublime \\ are both equally wrong-hea- \\ ded" (Thrift, 2004: 60).
}


és traduït en termes que comprenen els que menvolten es pot entendre aleshores com a emoció, en la seva qualitat de projecció o exposició del sentiment (Shouse, 2005). Aquesta importància que cal atorgar als afectes té a veure amb l'anomenat "gir afectiu" de les ciències socials i humanes que malda per capturar allò del cos que no es pot concebre mitjançant el pensament de caire representacional. Amb el gir afectiu, el cos guanya en rellevància si bé ja no és el mateix cos autocontingut d'abans.

Mentre que el pensament representacional es caracteritza per ser un mode d'anàlisi que tendeix a focalitzar en el discurs i la ideologia, i que assumeix que el fet de produir una representació discursiva del nostre objecte de recerca basta per il-lustrar-lo (Blackman i Venn, 2010: 9), a les teories de tipus no representacional l'èmfasi es posa en l'afectiu i en les sensacions. En el cas de les imatges, per exemple, Rebecca Coleman diu que en analitzar-les com a text desxifrem el seu missatge ideològic subjacent. Cossos i imatges són conceptualitzats separadament l'un de l'altre. Com que focalitzem en el contingut de la imatge, aquesta es pot entendre com a descripció d'un "món real”, d'un “cos real”. Coleman no posa en dubte que aquestes aproximacions siguin necessàries però ens diu que cal anar més enllà, car les imatges també ens afecten. Hem de saber veure les imatges no només com a representacions sinó en termes dels seus afectes (Coleman, 2013: 38). Prenem com a exemple unes imatges del gènere gore en les quals es mostra amb tota cruesa l'esbudellament d'un pobre desgraciat. Sabem que es tracta d'un assassinat, o més ben dit, de la representació d'un assassinat, car es tracta de ficció. Però tot i així, la sang de les imatges ens afecta, fins a tal punt que, tot $\mathrm{i}$ saber que és sang simulada, hi haurà qui preferirà aclucar els ulls.

\section{Cos i extensions}

Els clars límits amb els quals abans enteníem el cos trontollen quan l'entenem — com qualsevol altre objecte- dins d'un complex joc d'agències, d'afectes; quan tot seguint Andrew Pickering reconeixem que no són fets allò que constitueix el món en primera instància sinó les agències (Pickering, 1995: 6); agències, però, en el sentit de relacions, no com a quelcom que es posseeix (Barad, 2007: 178). On comença i on acaba un cos? Al mateix interrogant s'ha arribat també des d'un diferent punt de partença, el de les extensions corporals.

Poques dècades enrere, Marshall McLuhan (1994) parlava ja de les “extensions". Ell tenia molt clar que sense tot el que implica la tecnolo- 
gia seria impossible entendre què és l'ésser humà. Els artefactes tècnics repliquen o potencien habilitats del cos humà i per tant constitueixen extensions del cos tant des del punt de vista de l'acció física, com de la percepció i de la cognició. Ens desplacem més ràpidament (automòbil), hi veiem amb més nitidesa (ulleres) i pensem millor (ordinadors) gràcies a la tecnologia. Es tracta d'una problemàtica que ja des de fa temps preocupa també a la filosofia. El mateix Nietzsche ja deia que els instruments d'escriptura (la màquina d'escriure en aquell temps) contribueixen al desenvolupament de les nostres idees. A tall d'exemples d'extensions corporals Heidegger parlava del martell i Merleau-Ponty del barret amb plomes de les dones de l'època (Ihde, 2004: 14). La tecnologia potencia clarament el cos però el fet de parlar d'extensions ens fa qüestionar els mateixos límits corporals. Gregory Bateson, des de la teoria dels sistemes, agafant el bastó del cec com a exemple ja es feia aquesta pregunta:
"Suposem que soc cec i utilitzo un bastó blanc. Camino colpejant el terra amb ell, tap, tap, tap. On començo jo? Està el meu sistema mental limitat pel mànec de bastó? Està limitat per la meva pell? Comença en algun lloc situat a la meitat del bastó?" (Bateson, 1976: 489).

Quan parlem d'extensions corporals ens referim a l'acoblament d'un artefacte al cos. Quan aquests artefactes passen a formar part sistèmica de l'organisme humà parlem de "ciborgs", i del que ningú no pot albergar ja cap dubte és que aquest procés de ciborgització iniciat resulta imparable i s'anirà intensificant en les properes dècades.

Macgregor Wise ens resumeix a la perfecció els diferents tipus de relacions que establim entre humans i tecnologia, i que en el nostre cas podem aplicar també als cossos i objectes en general. A la primera d'elles es consideren els humans i les tecnologies com a dues coses completament diferents i que poden interactuar les unes amb les altres. D'aquesta manera, qualsevol tipus d'aparell, per exemple, es considera una mera eina externa a nosaltres. Dins d'aquesta visió es genera el debat de fins a quin punt som nosaltres els que controlem les tecnologies o són aquestes les que ens acaben —o acabaran — controlant a nosaltres. Una segona perspectiva demana que la relació humans/tecnologies sigui analitzada en context. Ni uns ni altres poden ser separats del context, això és el que explica la relació, però òbviament aquest posicionament continua considerant les tecnologies i les persones com dues coses diferents. La tercera perspectiva aborda la problemàtica a partir de l'articulació. Els diferents elements es poden connectar o desconnectar per tal de crear 
noves unitats o identitats (Wise, 2005: 81-83). Aquest darrer plantejament ens acosta ja a la perspectiva posthumanista, atès que l'acceptació plena d'aquesta relacionalitat ens duu forçosament a una nova ontologia.

No podem separar el cos del món dels objectes. El cos humà és el que és perquè al llarg de la història ha anat coevolucionant amb les coses. Segons escriu Nigel Thrift, l'evidència ens diu que òrgans com la mà, la panxa i altres complexos musculars i nerviosos s'han desenvolupat en part com a resposta a requeriments d'objectes, cosa que també ha produit canvis en el cervell (Thrift, 2007: 10). Quins són els límits del cos, doncs? Des d'una perspectiva posthumanista no està gens clar on comença i acaba un cos. Anant a les darreres conseqüències de la primitiva idea d'extensió tal com la va pensar McLuhan, es pot entendre el cos com un concepte evolucionari a partir del seu entorn tecnosocial i biocibernètic. Som, de fet, criatures protèsiques (Wolfe, 2009: XXV) sense que això es limiti ni molt menys a l'actual desenvolupament del món dels ciborgs que tant interessa al transhumanisme ${ }^{7}$.

Tal com ens diu Tamar Sharon, la idea d'extensió es pot conceptualitzar simplement com quelcom que es relaciona amb el cos, entenent-lo com a un tot coherent i unificat. Es tracta del cos entès de forma "molar" en el sentit de Deleuze ${ }^{8}$, una perspectiva en la qual el paradigma dualista de l'humanisme es manté a nivell de corporalitat. Però a aquest tipus de protesitat que Sharon anomena "suplementària" se li contraposa 1'"originària" que pressuposa una diferent formulació del cos, la organització del qual inclou i depèn d'objectes tecnològics "externs". Estem parlant d'un cos "molecular" per tant fet de fragments, un assemblatge constituit de parts transferibles i traslladables; es tracta d'una relació oberta que es pot compondre i descompondre mitjançant les interaccions amb tot el que l'envolta (Sharon, 2014: 113).

També en nous corrents de la biologia es tendeix a entendre l'organisme humà com a molecular, substituint així l'antiga visió molar del cos. Aquesta visió molecular entén la vida en termes de gens, proteïnes i enzims. Les tècniques que fan possible la molecularització de la vida assumeixen, a més, que aquestes entitats moleculars aillades i identificades es poden manipular i recombinar. Al nivell del codi genètic, la reconfiguració molecular dels organismes vius elimina diferències essencials entre cossos, manipulant i combinant gens de diferents espècies (Sharon, 2014: 113-118).

\footnotetext{
${ }^{7}$ No s'ha de confondre el "transhumanisme" amb el “posthumanisme”. De fet, el transhumanisme encarna valors propis de l'humanisme que col-lideixen amb fonaments teòrics del posthumanisme (Ferrando, 2013).

${ }^{8}$ El terme "molar" oposat a "molecular" és propi de la filosofia de Deleuze i Guattari. Parlem de "molar" en el sentit d'un tot identificable, talment com un organisme o societat en el qual entenem que hi ha relacions estables $i$ homogeneïtzades. "Molecular", en canvi, fa al-lusió a conjunts formats per elements relacionats no rígidament, amb límits fluctuants. El terme "molecular" no té res a veure amb la molècula en el sentit físic sinó que allò que es pretén amb aquest concepte és la desconstrucció de jerarquies. Aplicat al cos, una conceptualització molar l'entén com un tot orgànic unificat $\mathrm{i}$ separat del seu entorn, mentre que la molecular el considera com un conjunt de diferents parts o fragments que només esdevenen comprensibles a partir de les estretes interaccions amb tot allò que l'envolta.
} 
Una diferència fonamental entre la visió humanista i la posthumanista és que mentre la primera entén l'ésser humà en una relació antagònica amb tot el que l'envolta, la segona el conceptualitza com a corporeïtzat no només en un món tecnològic entès com a extensions sinó com a node resultant d'infinites relacions. Avui sabem que des del punt de vista biològic, la idea que "posseïm" un cos constitueix una fal-làcia. Les teories contemporànies de l'endosimbiosi ${ }^{9}$, $\mathrm{i}$ la transferència horitzontal de gens ${ }^{10}$ ens aporten nous models de la realitat en la qual es fractura la dicotomia organisme/entorn tot donant pas a un nou model de subjectivitat que s'oposa a l'unitari jo de la biologia zoocèntrica (Sharon, 2014: 139). El nostre cos és un massiu ecosistema microbià. Sabem que la nostra pell i el nostre estómac no poden funcionar sense l'ajut de bacteris. Però és molt més que això. El nostre cos posseeix deu vegades més bacteris que cèlllules. Dorion Sagan escrivia:

"El cos no és una entitat sinó la ficció d'una entitat bastida a base d'una massa d'entitats interactuants. Les capacitats del cos són literalment el resultat del que incorpora; el jo no és només corporal sinó corporatiu" (a Sharon, 2014: 139).

La visió d'una persona aferrada al mòbil ja sigui caminant pel carrer o en el transport públic forma part ja del nostre paisatge habitual. Resulta facil considerar aquest aparell com una mera pròtesi del cos humà. I de fet, els actuals estudis sobre ciència cognitiva ja apunten cap a la borrositat de límits entre el cos humà, el cervell i objectes inorgànics com smartphones o rellotges, de manera que aquests aparells esdevenen integrats a la ment, fent escàpol així les distincions ortodoxes entre mentcos, interior-exterior, o màquina-humà (Springwood, 2014: 463). Tal com escrivia Donna Haraway fa més de dues dècades, els nostres cossos van molt més enllà de la pell que els recobreix (1991: 178). Embodiment no és quelcom que s'hagi de limitar al cos físic, sinó que constitueix el canal mitjançant el qual el món ens toca, se'ns afegeix i fins i tot esdevé part de nosaltres (Malafouris, 2008: 1997).

\section{Assemblatges}

Des d'una perspectiva posthumanista, doncs, no és gens clar on comença i on acaba un cos. La idea d'assemblatge talment com ha estat treballada per Deleuze i Guattari, i més concretament per Manuel DeLanda ens ajuda a entendre els cossos com un producte sempre in becoming de relacionalitat. En aquest sentit ens va bé la noció de Coleman de bo-
9 "Endosimbiosi" és el nom que rep l'associació estreta entre espècies, en la qual individus d'una espècie resideixen dins de les cèl-lules de l'altra.

${ }^{10}$ Hom parla de transferència de gens "vertical" o "horitzontal" segons si el material genètic d'un organisme es transfereix dins o fora de la línia de descendència. 
dies in becoming (2008). La idea fa referència a procés, interconnectivitat i relacionalitat. Va més enllà de concepcions dualistes perquè implica un "estar entre", sempre esdevenint alguna cosa (Deleuze i Guattari, 1980: 339). Bodies in becoming en aquest sentit implica entendre els cossos - $\mathrm{i}$ el món en general - no com a quelcom estable i constituït per formes fixes o unitats discretes, molars, sinó com a processos de moviment, variació i multiplicitat (Coleman, 2008: 168).

Deleuze ens diu que tota relació de forces constitueix un cos, en el sentit general, ja sigui un cos químic, biològic, social o polític (1962: 45). Els cossos no són el lloc on actuen les forces, són la producció emergent de les interaccions d'aquestes forces. Fidels a la idea de descentrar, la unitat d'anàlisi no pren com a punt de partença l'agent humà sinó que allò que compta és l'assemblatge, i en tot assemblatge, allò vertaderament important — seguint Deleuze — “no és el que són els cossos, coses o institucions socials, ans les capacitats d'acció, interacció, sentiment i desig produït en cossos o grups de cossos per fluxos afectius" (Fox i Alldred, 2015: 402). Quan parlem d'assemblatge no ens referim a una simple configuració sinó que aquesta noció porta implícita la idea de moviment i connectivitat, d'agència processual. En el cas de l'assemblatge parlem d'articulació entre les parts que el componen; una articulació, però, constantment canviant tot creant així noves unitats o identitats (Wise, 2005: 83). Seguint Deleuze i Guattari, els assemblatges tenen les següents característiques ${ }^{11}$ :

1. Són relacionals. Estableixen relacions entre diferents elements. Aquestes relacions són, però, d'exterioritat, cosa que implica que qualsevol part que composa l'assemblatge es pot separar i incorporar en un diferent assemblatge en el qual les interaccions són diferents (DeLanda, 2006: 10). Casos típics per relacions d'interioritat són els organismes biològics. Deleuze empra exemples de simbiosi entre plantes i insectes pol-linitzants per a les relacions d'exterioritat (Deleuze, 1980: 17).

2. Són productius. Un assemblatge no s'ha d'entendre com una mera representació de la realitat sinó que — per emergència- es produeixen sentits que van més enllà dels elements presos per separat.

3. Són heterogenis. S’estableixen connexions entre elements de la més diversa natura, éssers orgànics, inorgànics, entitats socials o idees.

4. Els assemblatges es constitueixen per fluxos agèntics entre els elements que els composen.
${ }^{11}$ Aprofito en part la sistematització realitzada per Müller, 2015: 28. 
5. Creen territoris. Un assemblatge es pot conceptualitzar com a "territori” produït pels afectes entre relacions que es troben en un flux constant. Alguns d'aquests afectes estabilitzen l'assemblatge, d'altres el desestabilitzen o desterritorialitzen (Fox i Alldred, 2015: 401), de manera que aquests territoris es troben en transformacions constants. Les entitats heterogènies que configuren l'assemblatge interactuen en un moment determinat de la mateixa manera que poden deixar d'interactuar. Un assemblatge pot ser efímer, impredictible, és dinàmic, no estàtic.

Talment com entenem la noció d'assemblatge, en ell es produeix la dissolució d'agència i estructura, $\mathrm{i}$ atès que aquestes connexions són sòcio-materials es pot dir que se supera amb aquest plantejament la dicotomia natura/cultura (Bennett, 2010).

Dins de l'ontologia materialista de Deleuze i Guattari, el cos físic perd centralitat a favor del que ells denominaren el Cos sense òrgans (BwO). El $\mathrm{BwO}$ està constituit per una confluència d'elements, tant de tipus orgànic com no orgànic, de biologia, cultura i elements ambientals (Deleuze i Guattari, 1980: 185 i ss.). En aquest marc teòric, l'embodiment és quelcom molt més ampli a com — d'acord amb la formulació de Csordas (1999)— habitualment l'entenem. Es tracta del resultat emergent d'un complex joc d'interaccions (en el sentit d'intra-accions ${ }^{12}$ ) amb el món social i físic. Els cossos no constitueixen l'arena on actuen aquestes forces sinó que són el producte de la interacció de forces. Està clar que el cos de Deleuze i Guattari continua presentant característiques físiques $\mathrm{i}$ biològiques però pren en consideració molts altres elements. Talment com ens diu Nick Fox, el cos emergeix a partir d'una sèrie de relacions físiques, psicològiques i culturals; en aquest model no és que la societat "influeixi” en el cos: el BwO és al mateix temps biològic i social. Es tracta per tant d'una idea de cos molt més dinàmica i suggestiva que aquella en la qual sembla que el cos ja està totalment escrit en els gens o en la cultura (Fox, 2011: 360).

Abans dèiem que els assemblatges no són configuracions fixes sinó dinàmiques i canviants. Així, per exemple, quan jo m’assec en una cadira, aquesta passa a formar part de l'assemblatge del meu $\mathrm{BwO}$. Resultaria impossible retre compte de tots els elements que intervenen en un assemblatge però això no obsta perquè quan interessi focalitzem la nostra atenció en uns elements concrets i ben determinats. Més enllà del cos físic, tota relació de forces constitueix un cos, per exemple, el cos constituit per la relació persona-cadira. Assegut en un bar puc estar prenent una consumició, llegint o xerrant amb els companys. El meu cos forma part d'un assemblatge en el qual interactuen multitud d'ele-

\author{
${ }^{12}$ Karen Barad distingeix \\ “intra-acció" d'“interacció". \\ Quan parlem d"interacció” \\ ens referim a una relació entre \\ dues agències preconstituïdes \\ abans d'iniciar la interacció. La \\ “intra-acció", en canvi, implica \\ la mútua constitució d'agències \\ que emergeixen mitjançant la \\ seva intra-acció (Barad, 2007: \\ 33).
}


ments, entre d'altres la cadira en la qual m'assec i estableixo relacions d'afectes — afectes en el sentit de la capacitat d'afectar i ésser afectat. Per començar, l'agència de la cadira és allò que permet que jo disposi el meu cos en una posició estranya que difícilment podria mantenir sense quelcom que contrarestés la força d'atracció de la gravetat. Però més enllà d'aquest efecte, la mateixa constitució del moble pot implicar diferents fluxos afectius. Per constatar-ho només cal que fem una breu incursió als bars de la nostra localitat i fem l'exercici d'asseure'ns-hi per sentir els diferents seients. Hi ha, per exemple, les cadires de les terrasses dels locals fetes amb material sintètic. Em puc sentir còmode en elles i especialment quan tenen braços: entrecreuo les cames amb l'esquena lleugerament inclinada però ben recolzada al respatller. Aquesta manera de seure em genera una sensació de domini de la situació molt diferent a quan la cadira no disposa de braços i em fa tenir l'esquena completament vertical. El sentiment que genera una cadira sense braços és més aviat d'indefensió. Aquest sentiment es dilueix generalment ja sigui mitjançant postures corporals (per exemple creuant els braços) o bé perquè l'individu-cadira forma part d'un assemblatge en el qual intervenen més elements, com per exemple la taula on es disposa la consumició. De fet, aquestes cadires ja estan pensades com a complement de la taula; no endebades parlem d'asseure's a taula quan ens entaulem, tot i que òbviament és a la cadira on ho fem. Però si ara ens imaginem un espai buit amb un únic element, la cadira, és més facil apreciar la diferència de sentiments que fa experimentar una cadira amb braços o sense. Res més desconsolador que la imatge d'un encausat assegut en una cadira d'aquest tipus davant del tribunal que el jutja.

En el nostre breu recorregut pels bars de la ciutat podem constatar que són diverses les possibilitats que es donen als clients per asseure's, i si centrem l'atenció en la relació individu-moble no resulta difícil que un mateix pugui experimentar els diferents afectes que es transmeten. Un seient en forma de caixa de pocs centímetres d'alçada em fa sentir arrelat. Pel fet de ser baix, aquest seient mobliga a adoptar una posició corporal que em dóna més estabilitat que les cadires habituals. Succeeix en canvi tot el contrari en un tamboret alt en el qual els peus amb prou feines arriben a terra o em queden penjant; la transmissió d'afecte és d'inseguretat. Hi ha locals en els quals allò que trobem és un banc amb respatller en el qual s'hi poden encabir diverses persones; se'm desdibuixa la individualitat però ja em va bé si estic assegut amb companys o vull fer-ne de nous. Els tipus d'afectes que la cadira em pot transmetre en qualsevol d'aquests locals públics són diferents, i òbviament poden resultar reforçats, esmorteïts, cocreats o també anul·lats per altres elements 
que configuren l'assemblatge, siguin del caire que siguin, materials o no. Al capdavall sabem que la cadira no és un moble senzill. Res d'estrany que un arquitecte com Ludwig Mies van der Rohe parlés de la cadira com quelcom més enrevessat de construir que un gratacels (Tenner, 1996:168). Fins a quin punt la capacitat d'agència d'una cadira pot arribar a ser important ho sabia molt bé Glenn Gould, un dels pianistes més importants del segle passat. Aquest músic canadenc no se separava mai de la cadira que ja des de la seva infantesa emprava per tocar el piano. Se l'enduia als concerts i a les sales d'enregistrament, i li costava d'entendre que altres pianistes no haguessin tingut cap altre contacte amb el seient fins al mateix moment del concert. No era una qüestió de més o menys comoditat. Era per tota la munió d'afectes que la cadira li transmetia i que no en podia prescindir a l'hora de fer sonar l'instrument (Clarkson, 2010).

Més enllà de la funcionalitat usual que atorguem als objectes, doncs, una cadira pot fer molt més que garantir-nos més o menys comoditat; pot fer molt més que atorgar una nota de distinció o vulgaritat a l'espai. En el moment en el qual l'emprem, en el moment en què es pot parlar del cos individu-cadira pot fer sentir-nos diferents. Això passa amb qualsevol altre objecte. En els mites, rondalles i creences ja s'atorga tradicionalment poder a determinats objectes, el poder carismàtic en termes de Max Weber: l'espasa de Lohengrin, la vareta màgica de les fades, els talismans... Aquesta agència atorgada a determinats objectes en el món credencial no és sinó una ressonància amplificada de l'experiència que hom té en la vida quotidiana amb els fluxos afectius entre cos i objectes, en sigui o no conscient. El ceptre del rei no només és un símbol, ajuda també a sentir-se rei a qui l'empunya. Això ho sabem molt bé pel que es refereix a la indumentària. Un uniforme ajuda a generar els sentiments que associem a allò que representa; contribueix, per exemple que hom se senti metge, policia, presidiari, conserge, etc. Als EEUU, hi ha qui atorga molta importància al sentiment que genera el fet de dur un arma cenyida al cos, tant, que és motiu de discussió i debat el fet de si s'ha de considerar un dret civil la possibilitat de sentir-se persona-amb-un-arma mentre es transita per un espai públic. Segons ens diu Charles Springwood, als EEUU els fluxos afectius que es corresponen a dur armes de foc sembla que fins i tot puguin tenir un cert paper en les construccions de la masculinitat (Springwood, 2014: 464).

El mateix Glenn Gould abans esmentat afirmava que el músic acaba convertint-se en instrument del seu propi instrument, limitant la seva pròpia sensibilitat humana a l'expressivitat de la màquina (Sánchez, 2008: 163). Talment com escrivia Fernando Domínguez-Rubio ba- 
sant-se en el filòsof francès Simondon (Domínguez-Rubio, 2008: 90), els objectes no s'han d'entendre com a mera mediació entre uns suposats mons natural i humà: "La mediació entre l'ésser humà i el món esdevé ella mateixa un món, l'estructura del món” (Simondon, 1989: 181).

\section{Coda}

Dins de l'ontologia de caire no dualista que caracteritza el posthumanisme és a les relacions abans que a les entitats a allò que s'atorga una major importància. S'entén que les entitats o categories elementals no antecedeixen les relacions sinó que es constitueixen a partir de relacions. De fet, no som essències, som el resultat d'un joc infinit de relacions. Les entitats són moments concrets d'un constant fluir que es va construint en un complex espai relacional: "les coses i els éssers no són sinó formes materialitzades d'una continuïtat creativa”. Això va ser el que, segons Émile Durkheim, digué ja fa molt de temps un home savi dakota i que Claude Lévi-Strauss reproduí en el seu conegut text sobre totemisme (1965: 142; citat també a Pedersen, 2007: 314). Allò que és important retenir és que qualsevol cosa que ens puguem imaginar d'aquest món, ens materials i immaterials, orgànics i inorgànics són resultat d'efectes i al mateix temps efectes d'altres resultats. Això és doncs el que són els nostres cossos.

El posthumanisme malda per aconseguir una visió monista de la realitat, i això és el que fonamenta la idea ja esmentada que l'objecte és definit pel subjecte, i el subjecte per l'objecte. Hom parla en aquest sentit també de "materialisme relacional" que parteix de la base que tot allò social no és purament social:

"Els objectes, les entitats, els actors, els processos, tot són efectes semiòtics: els nodes són conjunts de relacions; o són conjunts de relacions entre relacions. Forcem la lògica un pas més enllà: els materials es constitueixen interactivament; fora de les seves interaccions no tenen ni existència ni realitat. Les màquines, la gent, les institucions socials, el món natural, la divinitat, tots són efectes o productes. És per aquesta raó que parlem de materialisme relacional" (Law i Mol, 1995: 277).

I en aquest sentit, sense la idea de relacionalitat seria impossible d'entendre què són els nostres cossos. Des d'una perspectiva teòrica de caire posthumanista, els nostres cossos s'han de concebre sempre com a productes i ensems efectes relacionals. 


\section{Bibliografia:}

Ahearn, L. M., Agency and language. A: J. Jaspers, J. Ostman i J. Verschueren, eds. 2010. Society and Language Use. Amsterdam: John Bengamins. pp. 28-48.

Akrich, M. i Latour, B., 1992. A Summary of a Convenient Vocabulary for the Semiotics of Human and Nonhuman Assemblies. A: W.E. Bijker i J. Law, eds. 1992. Shaping Technology/Building Society. Studies in Sociotechnical Change. Cambridge: MIT Press. pp. 259-64.

Barad, K., 2007. Meeting the Universe Halfway: Quantum Physics and the Entanglement of Matter and Meaning. Durham \& London: Duke University Press.

Bateson, G., 1976. Pasos hacia una ecología de la mente. Buenos Aires: Lohlé.

Baudrillard, J., 1969. El sistema de los objetos. México: Siglo XXI.

Bennett, J., 2010. Vibrant Matter. A political ecology of things. Durham: Duke University Press.

Blackman, L. i Venn, C., 2010. Affect. Body E Society, 16(1), pp. 7-28.

Bogost, I., 2012. Alien Phenomenology, or What It's Like to Be a Thing. Minneapolis: University of Minnesota Press.

Callon, M., 1986. Some elements of a sociology of translation: domestication of the scallops and the fishermen of St Brieuc Bay. A: J. Law, ed. Power, action and belief: a new sociology of knowledge? London: Routledge. pp. 196-233.

Clarkson, M., 2010. The Secret Life of Glenn Gould: A Genius in Love. Torinto: ECW Press.

Coleman, R., 2008. The becoming of bodies. Feminist Media Studies, 8(2), pp. 163-79.

Coleman, R., 2013. Transforming images: screens, affect, futures. London: Routledge.

Colman, F.J., 2010. Affect. A: A. Parr, ed. 2010. The Deleuze Dictionary. 2na edició. Edinburgh: Edinburgh UP. pp. 11-14.

Csordas, T., 1999. Embodiment and cultural fenomenology. A: G. Weiss i H. F. Haber, eds. 1999. Perspectives on Embodiment: The Intersections of Nature and Culture. London: Routledge. pp. 143-62.

DeLanda, M., 2006. A New Philosophy of Society: Assemblage Theory and Social Complexity. London \& New York: Continuum. 
Deleuze, G., 1962. Nietzsche et la philosophie. Paris: PUF.

Deleuze, G. i Guattari, F., 1980. Mille plateaux. Paris: Editions de Minuit.

Domínguez Rubio, F., 2008. La cuestión del objeto como cuestión sociológica. A: T. Sánchez-Criado, ed. 2008. Tecnogénesis: La construcción técnica de las ecologías humanas. Madrid: AIBR. Vol.1, pp. 81-111.

Domínguez Rubio, F., 2016. On the discrepancy between objects and things: An ecological approach. Journal of Material Culture, 21(1), pp. 59-86.

Elias, N., 1978. What is sociology. New York: Columbia University Press.

Esposito, R., 2015. Persons and Things: From the Body's Point of View. Cambridge: Polity Press.

Gell, A., 1998. Art and Agency: An Anthropological Theory. Oxford: Clarendon Press.

Ferrando, F., 2013. Posthumanism, Transhumanism, Antihumanism, Metahumanism, and New Materialisms: Differences and Relations. Existenz, 8(2), pp 26-32.

Fox, N. J., 2011. The ill-health assemblage: beyond the body-with-organs. Health Sociology Review, 20(4), pp. 359-71.

Fox, N.J. i Alldred, P., 2015. New materialist social inquiry: designs, methods and the research-assemblage. International Journal of Social Research Methodology, 18(4), pp. 399-414.

Giddens, A., 1984. The Constitution of Society. Cambridge: Polity Press.

Haraway, D., 1991. Simians, Cyborgs, and Women: The Reinvention of Nature. New York: Routledge.

Ihde, D., 2004. Los cuerpos en la tecnología. Nuevas tecnologías: nuevas ideas acerca de nuestro cuerpo. Barcelona: Editorial UOC.

Krause, S. R., 2011. Bodies in Action: Corporeal Agency and Democratic Politics. Political Theory, 39(3), pp. 299-324.

Latour, B., 2014. Agency at the Time of the Anthropocene. New Literary History, 45(1), pp. 1-18.

Law, J. i Mol, A., 1995. Notes on Materiality and Sociality. The Sociological Review, 43, pp. 274-94.

Leeuw, S.E. van der, 2008. Agency, Networks, Past and Future. A: C. Knappett i L. Malafouris, eds. 2008. Material Agency: Towards a Non-Anthropocentric Approach. New York: Springer. pp. 217-47. 
Lévi-Strauss, C., 1965. El totemismo en la actualidad. México: FCE.

McLuhan, M., 1994. Understanding Media: The Extensions of Man. Cambridge: The MIT Press.

Malafouris, L., 2008. Between Brains, Bodies and Things: Tectonoetic Awareness and the Extended Self. Philosophical Transactions of the Royal Society, 363(1499), pp. 1993-2002.

Martí, J., 2016. Cuerpo, sociedad y agencia: anorexia nervosa y blanqueamiento de piel. A: J. Martí i L. Porzio, eds. 2016. Cuerpos y agencia en la arena social. Madrid: CSIC. pp. 39-60.

Mazzei, L. A., 2013. A voice without organs: interviewing in posthumanist research. International Journal of Qualitative Studies in Education, 26(6), pp. 732-40.

Miah, A., 2009. A Critical History of Posthumanism. A: B. Gordijn i R. Chadwick, eds. 2009. Medical Enhancement and Posthumanity. Dordrecht: Springer Netherlands. pp. 71-94.

Müller, M., 2015. Assemblages and Actor-networks: Rethinking Socio-material Power, Politics and Space. Geography Compass, 9(1), pp. 27-41.

Pedersen, M.A., 2007. Multiplicity without myth: theorizing Darhad perspectivism. Inner Asia, 9(2), pp. 311-28.

Pickering, A., 1995. The Mangle of Practice: Time, Agency, and Science. Chicago: University Of Chicago Press.

Puig de la Bellacasa, M., 2009. Touching technologies, touching visions: The reclaim of sensorial experience and the politics of speculative thinking. Subjectivity, 28, pp. 297-315.

Sánchez Moreno, I., 2008. Cuando los Beatles se fueron de viaje, Glenn Gould se convirtió en piano. Nuevas tecnologías de la subjetivación en la música. A: T. Sánchez-Criado, ed. 2008. Tecnogénesis: La construcción técnica de las ecologías humanas. Madrid: AIBR. Vol. 1, pp. 139-172.

Sharon, T., 2014. Human Nature in an Age of Biotechnology: The Case for Mediated Posthumanism. Dordrecht: Springer Netherlands.

Shouse, E., 2005. Feeling, emotion, affect. M/C Journal 8(6), [online] Disponible a: <http://journal.media-culture.org.au/0512/03-shouse.ph> [consultat: febrer de 2017].

Simondon, G., 1989. Du monde d'existence des objects techniques. Paris: Aubier.

Springwood, C. F., 2014. Gun concealment, display, and other magical habits of the body. Critique of Anthropology, 34(4), pp. 450-71. 
Tenner, E., 1996. Why Things Bite Back: Technology and the Revenge of Unintended Consequences. New York: Vintage.

Thrift, N., 2000. Still Life in Nearly Present Time. Body E̋ Society, 6(3-4), pp. 34-57.

Thrift, N., 2004. Intensities of Feeling: Towards a Spatial Politics of Affect. Geografiska Annaler, 86B(1), pp. 55-76.

Thrift, N. 2007. Non-Representational Theory: Space, Politics, Affect. London \& New York: Routledge.

Welsch, W., 2014. Hombre y mundo: filosofía en perspectiva evolucionista. València: Pre-textos.

Westerman, F., 2006. El Negro. Eine verstörende Begegnung, Berlin: Links.

Wise, J. M., 2005. Assemblage. A: C. J. Stivale, ed. Gilles Deleuze: Key Concepts. Chesham: Acumen. pp. 77-87.

Wolfe, C., 2009. What Is Posthumanism? Minneapolis \& London: University of Minnesota Press.

Aquest article ha estat realitzat dins del projecte de recerca d'I+D+I El cos i el gènere dins del marc epistemológic i conceptual del posthumanisme (FEM2016-77963-C2-1-P).

\section{Josep Martí}

Antropòleg i exerceix la seva activitat professional com a investigador a la Institució Milà i Fontanals del CSIC a Barcelona. Els seus principals àmbits de recerca es circumscriuen a les àrees d'identitats collectives $\mathrm{i}$ cultura, antropologia de la música, creences i antropologia del cos. Ha realitzat treball de camp a l'estat espanyol, Alemanya, Itàlia (Sardenya), Japó i darrerament a Guinea Equatorial. Com a docent convidat imparteix cursos dins de la seva especialització en diferents universitats del país. 